\title{
THE RISK OF DEVELOPMENT OF LITHUANIAN DERIVATIVES MARKETS
}

\author{
Kristina GARŠKAITE்-MILVYDIENE்* \\ Faculty of Business Management, Vilnius Gediminas Technical University, Vilnius, Lithuania
}

Received 06 May 2020; accepted 25 September 2020

\begin{abstract}
Derivative financial instruments play a very important role in financial markets, but they are seen as rather contradictory and their impact on financial markets and the stability of these markets has not been comprehensively examined. Therefore, the aim of this article is to systematise the potential risks of derivatives in the context of the past global financial crisis, and the recent situation in Lithuania. In particular, growing international tension and deteriorating economic situation, make it necessary to re-analyse the recent crisis, its causes and consequences. The 2007-2008 global financial crisis revealed the challenges and risks of derivatives and showed the tremendous impact that their imprudent use may have on the stability of a financial system. The Lithuanian economy recently joined the euro, but its macroeconomic fundamentals show certain risks. Infrastructures of the derivatives market, liquidity and an adequate supervisory framework are necessary to maintain stability.
\end{abstract}

Keywords: derivatives, financial instrument, risk, foreign exchange transactions and interest rate contracts, financial crisis, causes and consequences of financial crisis.

JEL Classification: G01, G10, G24, G32, M21.

\section{Introduction}

Over the last decades, the global securities market has advanced considerably, and new financial instruments have emerged thus reducing the dependence of countries on the banking sector and also meeting the need for financial diversification (Hull, 2012; Blanco \& Wehrheim, 2017; Carroll et al., 2017). The development of the derivatives market has been particularly prominent (Brigham \& Davies, 2016; Geyer-Klingeberg et al., 2018). In order to distribute risk among countries, derivatives are used extensively and increasingly in risk management (Kosowski \& Neftci, 2015; Bardoscia et al., 2019; Sakurai \& Kurosaki, 2020). In 2007, at the onset of the U.S. financial crisis, which in 2008 gained enormous momentum not only in the USA, but spread around the world directly affecting Europe and indirectly spreading to emerging markets (Kazi et al., 2013; Lel, 2014; Mayordomo et al., 2014). The

${ }^{\star}$ Corresponding author. E-mail: kristina.garskaite-milvydiene@vilniustech.lt 
crisis highlighted the risks of derivatives and the ways of manifestation of such risks (Obstfeld \& Rogoff, 2009; Hentschel \& Smith, 2020).

It is important not only for banks, but also for the economy as a whole to consider how the growing use of derivatives affects the stability of financial markets (Gródek-Szostak et al., 2019; Sarveswara Reddy \& Sathish, 2020), what were the causes and consequences of the 2007-2008 global financial crisis (Bank for International Settlements [BIS], 2014; Oldani, 2008; Foster \& Magdoff, 2009; Jacopo et al., 2009; Borger, 2020). Scientific literature offers a diverse analysis of derivatives which is nevertheless insufficient not only to comprehensively consider the positive impact of these instruments on financial markets, but also to reveal the potential threats and risks of these instruments and how these risks may manifest themselves (Hoa et al., 2013; Vo et al., 2019a). Therefore, the impact of derivatives on financial markets and associated risks remain a topical research issue.

The aim of this paper is to analyse and systematise the advantages of derivatives in the context of recent decades, to analyse the dynamics of derivatives in Lithuania during 20042016, as well as to forecast their future trends.

The object of the research is derivatives and related risks, their development (progress).

Research methods. The paper employs the methods of systemic analysis of scientific literature, statistical analysis, logical comparative analysis and generalisation.

The structure of the paper consists of an introduction, five explanatory parts and conclusions. The first part provides an overview of the development of the Lithuanian economy. In the second part, the analysis of derivatives and its structure is performed. The third part presents the riskiness of the derivatives market. The next section presents research on the situation in Lithuanian derivative markets. The last section presents a forecast of derivatives transactions and currency pairs.

\section{Overview of the development of the Lithuanian economy}

In order to overview the development of the Lithuanian economy from the perspective of growing international tension and deteriorating economic situation, this paper analyses several key economic indicators revealing the context of the progress of derivatives (Burns \& Tobin, 2016; Lietuvos bankas [LB], 2016, 2019b; Burns et al., 2019). In this way, it can be stated that global economic activity has recently remained at quite high levels, but its development in different regions is becoming less uniform (Vo et al., 2019b). Foreign trade development declined in developed countries, namely, in the euro area, Japan, and some other countries. It is in this group of countries that in 2017 economic activity jumped the most thus boosting global economic development, however most macroeconomic indicators in these countries have recently become less strong, with slower growth in manufacturing, imports and exports and decreasing confidence indicators (LB, 2016, 2018, 2019a).

Uncertainty over the prospects of international trade is becoming increasingly important for such trade (Barron \& Hultén, 2011; Vo et al., 2019b). The direct effect of the introduced trade restrictions is limited, as these restrictions apply only to a relatively small part of global trade. A much greater impact both on trade flows and economic activity can be attributed to the risk of increasing trade tensions and growing distance from achievements in the area 
of free trade. Tighter restrictions on trade would increase costs for businesses, reduce the purchasing power of the population, which could affect household consumption, investment, and labour market indicators.

A slower growth of demand in trading partners affects Lithuanian exports (Figure 1). The exports of goods of Lithuanian origin are increasing at slower pace than last year. Such a slowdown in growth is mostly attributed to a weaker growth in demand in EU countries. The growth of re-exports has almost completely waned. Russian imports, having increased considerably last year, significantly boosted Lithuania's re-exports to this country, while this year, as the growth of Russian imports slowed down, re-exports almost stopped increasing.

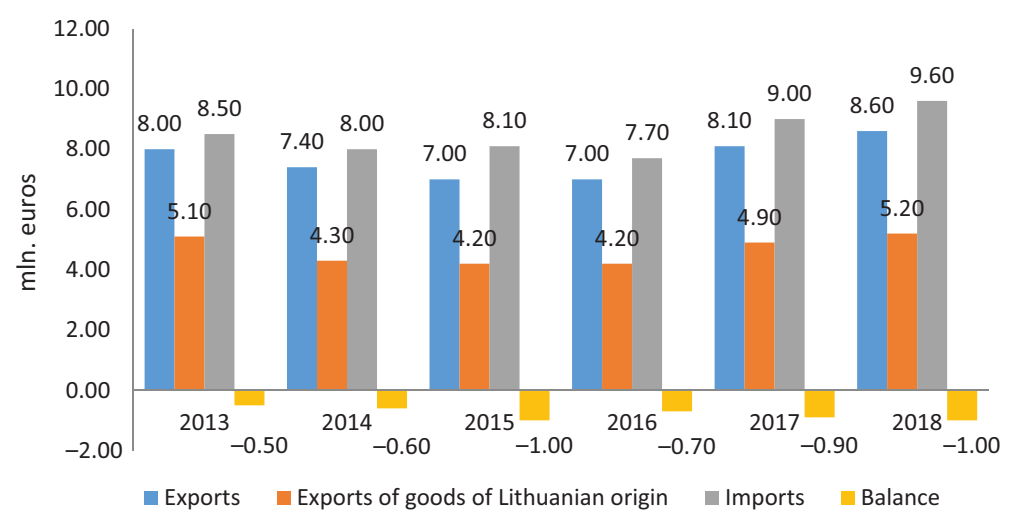

Figure 1. Lithuanian exports and imports during 2013-2018 (source: LB, 2019a)

Inflation, as a long-term increase in the general level of prices, has a major influence on the processes taking place in the country. As prices rise, the purchasing power of money decreases. It is argued that inflation rates can be boosted by the rate of GDP growth, however higher rates of inflation can lead to economic decline (Wang, 2017). Figure 2 below demonstrates the rate of inflation in Lithuania in the 2008-2018 period.

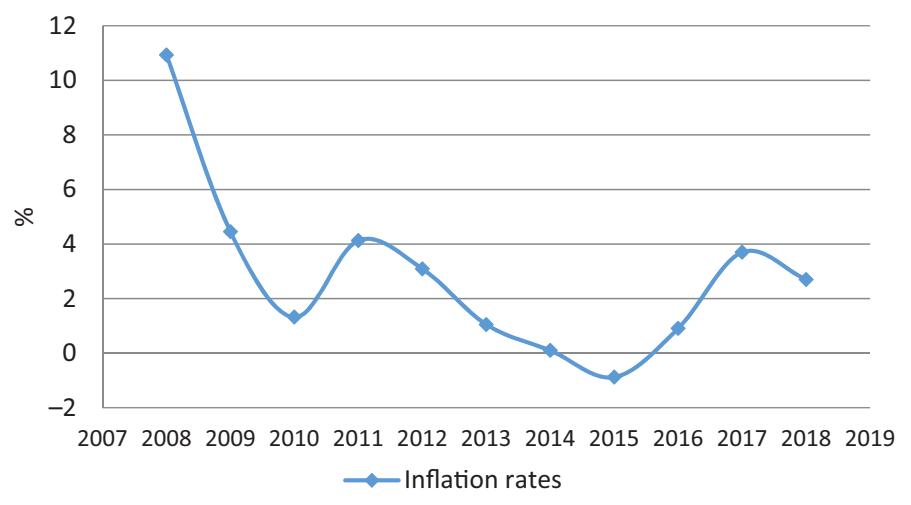

Figure 2. Inflation rates in Lithuania

(source: BIS, 2019b; European Central Bank, 2019; LB, 2019a) 


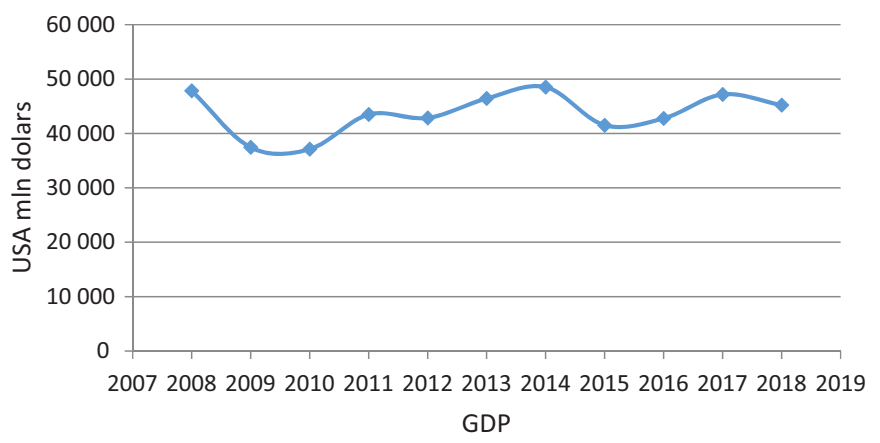

Figure 3. Lithuania’s GDP during 2008-2018 (source: LB, 2019)

The overall annual inflation rate remains on a downward trend. Fluctuations in inflation are mainly influenced by prices linked with global markets of raw materials. With the rapid growth of the global economy, rising demand has a stimulating effect on oil prices, which is also maintained by supply constraints on the countries that produce this raw material. Rising fuel prices currently increase overall inflation rates more than prices of other commodity and service groups. Food prices are also pushing up inflation rates, though less than predicted. As stocks have been accumulated and supply is sufficient, most prices of food raw materials, other than grain crops, are falling on world markets. For this reason, food prices are increasing slower also for consumers. Net inflation, including prices of services and industrial goods, has also fallen slightly. Disregarding the mentioned price effects, net inflation remains fairly stable as it continues to be driven by rising labour costs and domestic demand.

An overview of Lithuania's GDP during 2008-2018 (see Figure 3) shows that constant fluctuations of GDP. In 2008, it amounted to 47.85 billion U.S. dollars, then dropped in 2010 to 37.12 billion U.S. dollars, however later started to rise again and in 2014 reached 48.52 billion U.S. dollars (LB, 2019a).

The macroeconomic indicators under analysis influence the Lithuanian market, including changes in derivatives, their development and the forms and tendencies of their risk manifestations. After reviewing the development of the Lithuanian economy in the context of growing international tensions and increasingly complicated economic situation, the author proceeds to examine the development of derivatives.

\section{What are derivatives?}

Derivatives are spreading rapidly around the world due to globalisation and financial integration (David, 2009; Bae et al., 2017; Inekwe, 2018; Vo et al., 2019a, 2019b). Especially for young growing markets, it is a matter of importance to identify these instruments and the risks associated with them (Bartram et al., 2009; Foster \& Magdoff, 2009; Hentschel \& Smith, 2020). It is therefore important to systematise and distinguish the most important forms of risk manifestations in relation to derivatives in order to identify and properly manage such risks (Vo et al., 2019a; Sakurai \& Kurosaki, 2020).

Derivatives can be defined as instruments for transferring financial risk to a third party when the title to the underlying is not transferable (Lietuvos Respublikos Seimas [LRS], 2007; 
Bezzina \& Grima, 2012; Bae et al., 2017). Typically, derivatives improve the distribution of risk within a financial system. There are two ways to do this: firstly, derivatives make risk management more effective and flexible, especially in banks, and secondly, derivatives help to more effectively distribute individual risks and reduce the overall economic risk associated with them (Bingham \& Rüdiger, 2013; Bae et al., 2017; Geyer-Klingeberg et al., 2018). Derivatives may be used not only for hedging purposes but also for speculative or arbitration purposes (Akbar et al., 2013; Bingham \& Rüdiger, 2013; Bae et al., 2017).

An analysis of derivatives shows that their use is usually referred to as an advantage in improving certain factors:

- hedging. These are instruments for banks and other institutions to protect themselves against risks related to certain circumstances (Crotty, 2009; Bingham \& Rüdiger, 2013; Brigham \& Davies, 2016; Hentschel \& Smith, 2020). The costs of hedging are lower compared to syndication of loans. Derivative financial instruments may have various modifications related to different risk profiles. If such techniques are widely used, they are beneficial for the entire system;

- liquidity. Transactions in derivatives increase the liquidity of the banking sector. As bank risk exposure is limited (and passed on to other parties, such as insurance companies or pension funds), banks can lend more funds to different enterprises (Jankensgard, 2013; Wang, 2017; Höing \& Kunstein, 2018; Bardoscia et al., 2019);

- stability of the financial sector. By enhancing risk spreading both in the national economy and globally, derivatives improve the stability of not only banks, but also of the financial system itself (Akbar et al., 2013; Vo et al., 2019b). Risk can be passed from high-risk sectors on to those sectors that can take it, thus distributing it among hedge funds, investment funds or insurance companies. In this way, economic shocks, such as economic slowdown or crises in certain sectors, may be easier to survive (Bingham \& Rüdiger, 2013; Braendle, 2018).

- market information on risk. The value of derivative financial instruments performs a valuable information function. Their valuation provides better and timely information about an enterprise's financial position compared to credit ratings. Although credit ratings are most widespread as the indicators of stability and reliability published by credit rating agencies, and despite their considerable importance for markets, ratings undoubtedly have weaknesses (Melvin \& Taylor, 2009; Murphy, 2013; Swedbank, 2017; LB, 2018; SEB bankas, 2018; Sarveswara Reddy \& Sathish, 2020).

However, beside advantages, the use and development of derivatives can cause certain problems. The following shortcomings are highlighted:

- systemic risk in the derivatives market. Many investors, in particular hedge funds, are hedged by means of derivative financial instruments (Rutkauskas et al., 2008; Bardoscia et al., 2019; Sakurai \& Kurosaki, 2020). Relatively minor changes in this market can cause huge problems throughout the system, in particular, by causing liquidity problems in financial markets. Although derivatives may reduce systemic risk, the opposite can also happen (Reddy et al., 2014; Garskaite-Milvydiene \& Burksaitiene, 2016; Geyer-Klingeberg et al., 2018). This is what happened in 2008, when due to the high value of derivatives the U.S. crisis spread to and struck international financial markets;

- fairly high market concentration. When there is a high degree of concentration in the market, this constitutes an obstacle to the economically optimal distribution of risk, 
even if it does not directly threaten the stability of financial markets. The high degree of concentration in the derivatives market is very common for the U.S., which means that there are few players on the market, but they are large. If one of these large players went bankrupt, this would lead to difficulties also for other market participants, and at the same time transaction costs would increase (Melvin \& Taylor, 2009; McKibbin \& Stoecke, 2010; Marshall et al., 2013; Hentschel \& Smith, 2020);

- price distortions. Although there are no explicit indications that derivatives may be systemically mispriced, the lack of experience of new participants entering the market may lead to such assumptions. Systemic mispricing may lead to misallocation of resources (Gay et al., 2011; Gródek-Szostak et al., 2019). The main danger is that market participants may underestimate the actual risk and assume more risk than would be desirable for the whole economy, which would lead to misallocation of resources among market participants. Mispricing can also give wrong information to other market participants about events (Naiker et al., 2013; Wang, 2017; Su et al., 2018);

- reduced role of banking supervision. Counterparties to derivatives transactions must assume the role of bank control, as appropriate, in relation to the risks involved. The hedge funds selling derivative financial instruments may act as active controllers of the enterprises which are counterparties to the derivatives transactions (Begg, 2009; Bingham \& Rüdiger, 2013; Li \& Marinc, 2014; Quaglia, 2013; Braendle, 2018);

- insufficient regulation of the derivatives market. The derivatives market is not very transparent. Derivatives themselves are rather non-regulated, documentation practices need to be improved. As a result, the derivatives market is not sufficiently clear about the risk assumed and the nature and source of this risk. Such uncertainty has negative consequences. The main players in this market can influence the regulatory rules being developed, which may harm the interests of other countries (Oldani, 2018). Although standardisation has reduced transaction costs, legislative interventions in this area still need to be improved, and there remain documentation shortcomings (Donohoe, 2015; Müller et al., 2015; Braendle, 2018; Nedelchev, 2018; Hentschel \& Smith, 2020).

Like most or even all financial assets, derivatives are also risky. Investors must assess the risk they take and at the same time identify the risks arising from the derivatives that they want to invest in. The risk of investing in derivatives differs from the usual risk of investing directly in the assets underlying the derivatives (Carruthers, 2013; Sakurai \& Kurosaki, 2020). The key difference is that investing in assets can, in the worst-case scenario, result in the loss of all the invested assets, while investing in derivatives can lead to both the loss of invested assets and the taking of additional financial obligations. The following key risks associated with derivatives are distinguished (Silvo et al., 2012; Akbar et al., 2013; Thapa et al., 2016; Parlapiano et al., 2017; Shil \& Das, 2017):

- risk of a change in value. The value of derivatives depends both on the price of the underlying asset and residual maturity. Therefore, it has been found that a change in the price of a derivative would be greater than a change in the price of the underlying asset if the price of the underlying asset changed. This is due to the so-called leverage effect. The biggest changes in the prices of derivatives occur when there is little time left to maturity (Geyer-Klingeberg et al., 2018; Su et al., 2018);

- risk of losing more than has been invested. Some derivatives are, due to their contractual terms, classified as instruments with unlimited risk (future, forward, other 
complex derivatives) that, in the event of a failure, may create additional obligations for the buyer (Aysun \& Guldi, 2011; Silvo et al., 2012; Hentschel \& Smith, 2020). According to risk exposure, derivatives are classified as high-risk instruments, when invested assets are at risk, and very high-risk instruments, where the risk is higher than the invested assets.

\section{Riskiness of the derivatives market}

The recent situation, viewed from the perspective of growing international tension, makes it necessary to re-examine the past crisis, its causes and consequences (Reddy et al., 2014; Garskaite-Milvydiene \& Burksaitiene, 2016). It is recalled that the 2007-2008 global financial crisis was distinguished by its rapid spread and strength multiplied by the use of derivatives (Akbar et al., 2013; Chang et al., 2018). The scale and speed of this crisis were considerable for a number of reasons. Firstly, these asset backed securities have the market values that fell instantly in the wake of the crisis (Mayordomo et al., 2014; Müller et al., 2015). Secondly, the emergence of this crisis was caused by a sharp increase in financial leverage, both at the level of households and that of financial institutions, which was further strengthened by the rapid growth of credit derivatives, although these measures were specifically designed to hedge the risk of such leverage increase. These reasons led to a rapid decline in asset values, financial leverage and asset sales volumes (Melvin \& Taylor, 2009; McKibbin \& Stoeckel, 2010). Due to globalisation and financial integration, the crisis quickly spread outside the USA both among countries and financial institutions, namely, banks, pension funds, insurance companies, etc. (Kazi et al., 2013; Lel, 2014).

Yet another reason was related to credit ratings (Donohoe, 2015). Too much trust was put in credit agencies' ratings. In the case of derivative securities, a large share of second-rate and risky assets was converted into AAA-rated assets, which seemed to be a safe investment. In this way, a huge risk was assumed. This led to significant changes in the credit rating industry. The increased competition arising in the credit rating industry could solve certain problems (Melvin \& Taylor, 2009; McKibbin \& Stoeckel, 2010; Bardoscia, et al., 2019).

Thus, derivatives had a rather negative impact on the stability of the financial system as a whole, although derivatives should help to maintain the stability of the financial system under certain conditions. Firstly, risk must be carefully assessed and estimated; secondly, risk must be properly managed; thirdly, systemic liquidity must be ensured (Hoa et al., 2013; Reddy et al., 2014; Eilifsen \& Quick, 2018; Inekwe, 2018).

Thus, the global financial crisis has highlighted the shortcomings of the market for conventional instruments and derivatives. As it has become apparent that there is a lack of sufficient information, sufficient risk monitoring, sufficient liquidity in financial markets, and market infrastructure is weak and the whole system is dynamic (where the uniform behaviour of individual market participants causes a wave of change across the system), there has emerged the need to reform this market with a view to reducing the riskiness of the market for conventional instruments and derivatives (Reddy et al., 2014; Garskaite-Milvydiene \& Burksaitiene, 2016; Su et al., 2018).

In order to eliminate the shortcomings, firstly, attempts were made to ensure transparency in the derivatives market and the intervention of certain government institutions was 
needed in order to regulate this market for financial instruments, and secondly, market infrastructure had to be improved (Murphy, 2013; Reddy et al., 2014; Müller et al., 2015). The aim was for the majority of the instruments to be traded on stock exchanges. This helped to control the risks associated with counterparties as well as operational risk (Iba \& Aranha, 2012; Kosowski \& Neftci, 2015). Market participants had to register derivatives transactions, and this information also had to be made available to other market participants. Moreover, information on historical prices of instruments in certain segments of this market had to be provided centrally (Müller et al., 2015; Vo et al., 2019b; Sarveswara Reddy \& Sathish, 2020).

Thus, in order to identify and properly manage the risks of the derivatives market (McKibbin \& Stoeckel, 2010; Inekwe, 2018; Bardoscia et al., 2019; Hentschel \& Smith, 2020), as these instruments are spreading into new markets that are not yet well-developed, and in addressing issues in existing markets, an analysis of the mentioned potential prudential measures and ways to address market problems has been undertaken following the financial crisis and facing a potential new crisis.

\section{Analysis of the situation in Lithuanian derivative markets}

In 2016, the Bank of Lithuania repeatedly participated in preparing a survey of global foreign exchange and derivatives markets, which is drawn up every three years (Swedbank, 2017; LB, 2016, 2018; SEB bankas, 2018). It is prepared by the Bank for International Settlements (BIS, 2018a, 2018b) together with the central banks and monetary authorities of 52 countries. The Bank of Lithuania has participated in the preparation of such surveys since 2004, with the banks and branches of foreign banks actively operating in local and international foreign exchange and derivatives markets being selected for this purpose (LRS, 2007; LB, 2016, 2018). Since 1996, the Bank for International Settlements has periodically provided financial markets with statistical information on the derivatives market, its size and structure.

The global survey conducted in 2016 featured data of more than 1200 key market participants worldwide concerning their conventional foreign exchange transactions (spot, forwards and swaps) and OTC derivatives activity in April (BIS, 2018a, 2018b). The survey conducted in Lithuania covered six banks and branches of foreign banks whose share in the country's foreign exchange and derivatives markets makes up 97\% (LB, 2016, 2018, 2019a).

Compared to findings of the previous survey, the Lithuanian foreign exchange and derivatives market has shrunk by more than half over three years. However, it should be noted that this year, Lithuania participated in the survey as a member of the euro area. In Lithuania, the turnover in the foreign exchange market in April 2006 amounted to 4.9 billion U.S. dollars (the turnover attributable to transactions per business day averaged 0.2 billion U.S. dollars). FX swaps accounted for $57 \%$ and spot transactions - for $41 \%$ of the monthly turnover (Table 1) (LB, 2016, 2018; BIS, 2018a, 2018b).

Summarising the data contained in Table 1 and highlighting the key transactions, Figure 4 shows the structure of certain transactions (LB, 2016, 2018; BIS, 2018a, 2018b). It demonstrates that since 2004, the percentage of spot transactions (futures) in the overall transaction structure has decreased, and only from 2013 onwards, there has been observed a slight upward trend. Looking at the period under review, it is clear that since 2004, FX swaps have clearly grown in the overall structure of transactions. 
Table 1. Turnover in the Lithuanian foreign exchange market by transactions, counterparty and maturity (nominal or notional transaction amounts in April 2016; millions of U.S. dollars) (source: LB, 2016, 2018, 2019b; BIS, 2018a, 2018b)

\begin{tabular}{|c|c|c|c|c|c|c|c|c|c|c|}
\hline \multirow{2}{*}{$\begin{array}{l}\text { Transactions and } \\
\text { counterparties }\end{array}$} & \multicolumn{2}{|c|}{2004} & \multicolumn{2}{|c|}{2007} & \multicolumn{2}{|c|}{2010} & \multicolumn{2}{|c|}{2013} & \multicolumn{2}{|c|}{2016} \\
\hline & amount & $\begin{array}{c}\text { share, } \\
\%\end{array}$ & amount & $\begin{array}{c}\text { share, } \\
\%\end{array}$ & amount & $\begin{array}{c}\text { share, } \\
\%\end{array}$ & amount & $\begin{array}{c}\text { share, } \\
\%\end{array}$ & amount & $\begin{array}{c}\text { share, } \\
\%\end{array}$ \\
\hline $\begin{array}{l}\text { Spot transactions } \\
\text { (futures) }\end{array}$ & 19585.9 & 89 & 11946.7 & 69 & 5462.7 & 23 & 3517.1 & 32 & 2016.8 & 41 \\
\hline $\begin{array}{l}\text { - with reporting } \\
\text { dealers }\end{array}$ & 2724.4 & 14 & 3320.8 & 28 & 1716.0 & 31 & 659.6 & 19 & 463.0 & 23 \\
\hline $\begin{array}{l}\text { - with other } \\
\text { financial institutions }\end{array}$ & 15550.1 & 79 & 4681.2 & 39 & 1568.8 & 29 & 222.1 & 6 & 155.3 & 8 \\
\hline $\begin{array}{l}\text { - with non-financial } \\
\text { customers }\end{array}$ & 1311.4 & 7 & 3944.7 & 33 & 2177.9 & 40 & 2635.4 & 75 & 1398.5 & 69 \\
\hline Forwards & 372.5 & 2 & 220.6 & 1 & 363.4 & 0 & 49.1 & 0 & 70.4 & 1 \\
\hline $\begin{array}{l}\text { - with reporting } \\
\text { dealers }\end{array}$ & 248.0 & 67 & 99.6 & 45 & 336.3 & 93 & 6.5 & 13 & 16.6 & 24 \\
\hline $\begin{array}{l}\text { - with other } \\
\text { financial institutions }\end{array}$ & 53.3 & 14 & 92.8 & 42 & 8.6 & 2 & 16.2 & 33 & 11.1 & 16 \\
\hline $\begin{array}{l}\text { - with non-financial } \\
\text { customers }\end{array}$ & 71.3 & 19 & 28.1 & 13 & 18.5 & 5 & 26.4 & 54 & 42.7 & 61 \\
\hline $\begin{array}{l}\text { Foreign exchange } \\
\text { swaps }\end{array}$ & 2026.3 & 9 & 5171.3 & 30 & 17995.9 & 74 & 7507.3 & 68 & 2810.0 & 57 \\
\hline $\begin{array}{l}\text { - with reporting } \\
\text { dealers }\end{array}$ & 1780.5 & 88 & 4225.9 & 82 & 17308.9 & 96 & 7283.6 & 97 & 2601.6 & 93 \\
\hline $\begin{array}{l}\text { - with other } \\
\text { financial institutions }\end{array}$ & 191.4 & 9 & 471.0 & 9 & 273.6 & 2 & 93.2 & 1 & 21.0 & 1 \\
\hline $\begin{array}{l}\text { - with non-financial } \\
\text { customers }\end{array}$ & 54.5 & 3 & 474.4 & 9 & 413.4 & 2 & 130.5 & 2 & 187.4 & 7 \\
\hline $\begin{array}{l}\text { Cross-currency } \\
\text { interest rate swaps }\end{array}$ & - & - & - & - & 400.0 & 2 & - & - & - & - \\
\hline $\begin{array}{l}\text { - with reporting } \\
\text { dealers }\end{array}$ & - & - & - & - & 200.0 & 50 & - & - & - & - \\
\hline $\begin{array}{l}\text { - with other } \\
\text { financial institutions }\end{array}$ & - & - & - & - & - & - & - & - & - & - \\
\hline $\begin{array}{l}\text { - with non-financial } \\
\text { customers }\end{array}$ & - & - & - & - & 200.0 & 50 & - & - & - & - \\
\hline $\begin{array}{l}\text { Currency options } \\
\text { (over-the-counter) }\end{array}$ & 0.7 & 0 & 0.9 & 0 & 15.7 & 0 & 15.1 & 0 & 0.4 & 0 \\
\hline $\begin{array}{l}\text { - with reporting } \\
\text { dealers }\end{array}$ & 0.3 & 50 & 0.3 & 32 & 2.4 & 15 & 1.9 & 12 & 0.2 & 50 \\
\hline $\begin{array}{l}\text { - with other } \\
\text { financial institutions }\end{array}$ & - & - & - & - & - & - & - & - & - & - \\
\hline $\begin{array}{l}\text { - with non-financial } \\
\text { customers }\end{array}$ & 0.3 & 50 & 0.6 & 68 & 13.3 & 85 & 13.3 & 88 & 0.2 & 50 \\
\hline
\end{tabular}


End of Table 1

\begin{tabular}{|c|c|c|c|c|c|c|c|c|c|c|}
\hline \multirow{2}{*}{$\begin{array}{l}\text { Transactions and } \\
\text { counterparties }\end{array}$} & \multicolumn{2}{|c|}{2004} & \multicolumn{2}{|c|}{2007} & \multicolumn{2}{|c|}{2010} & \multicolumn{2}{|c|}{2013} & \multicolumn{2}{|c|}{2016} \\
\hline & amount & $\begin{array}{l}\text { share, } \\
\%\end{array}$ & amount & $\begin{array}{c}\text { share, } \\
\%\end{array}$ & amount & $\begin{array}{c}\text { share, } \\
\%\end{array}$ & amount & $\begin{array}{c}\text { share, } \\
\%\end{array}$ & amount & $\begin{array}{c}\text { share, } \\
\%\end{array}$ \\
\hline $\begin{array}{l}\text { Total foreign } \\
\text { exchange market } \\
\text { turnover }\end{array}$ & 21985.5 & 100 & 17339.5 & 100 & 24237.8 & 100 & 11088.6 & 100 & 4897.6 & 100 \\
\hline $\begin{array}{l}\text { - with reporting } \\
\text { dealers }\end{array}$ & 4753.2 & 22 & 7646.6 & 44 & 19563.7 & 81 & 7951.5 & 72 & 3081.4 & 63 \\
\hline $\begin{array}{l}\text { - with other } \\
\text { financial institutions }\end{array}$ & 15794.8 & 72 & 5245.0 & 30 & 1851.0 & 8 & 331.5 & 3 & 187.5 & 4 \\
\hline $\begin{array}{l}\text { - with non-financial } \\
\text { customers }\end{array}$ & 1437.5 & 7 & 4447.8 & 26 & 2823.1 & 12 & 2805.6 & 25 & 1628.8 & 33 \\
\hline - local & 1552.6 & 7 & 7507.5 & 43 & 4450.2 & 18 & 2955.9 & 27 & 1622.1 & 33 \\
\hline - cross-border & 20432.8 & 93 & 9831.7 & 57 & 19386.5 & 80 & 8132.9 & 73 & 3275.6 & 67 \\
\hline Forwards & 372.5 & 100 & 220.6 & 100 & 363.5 & 100 & 49.1 & 0 & 70.4 & 100 \\
\hline - up to 7 days & 98.8 & 27 & 31.2 & 14 & 0.6 & 0 & 1.6 & 3 & 3.9 & 6 \\
\hline $\begin{array}{l}\text { - over } 7 \text { days and } \\
\text { up to } 1 \text { year }\end{array}$ & 273.8 & 74 & 189.4 & 86 & 362.1 & 100 & 44.5 & 91 & 66.5 & 94 \\
\hline - over 1 year & - & - & - & - & 0.8 & 0 & 3.1 & 6 & - & - \\
\hline $\begin{array}{l}\text { Foreign exchange } \\
\text { swaps }\end{array}$ & 2026.1 & 100 & 5171.3 & 100 & 17995.9 & 100 & 7507.0 & 100 & 2810.0 & 100 \\
\hline - up to 7 days & 1319.0 & 65 & 2984.8 & 58 & 17245.0 & 96 & 6985.2 & 93 & 2526.1 & 90 \\
\hline $\begin{array}{l}\text { - over } 7 \text { days and } \\
\text { up to } 1 \text { year }\end{array}$ & 707.2 & 35 & 2184.7 & 42 & 755.0 & 4 & 520.3 & 7 & 283.9 & 10 \\
\hline - over 1 year & - & - & - & - & 0.1 & 0 & 1.5 & 0 & - & - \\
\hline
\end{tabular}

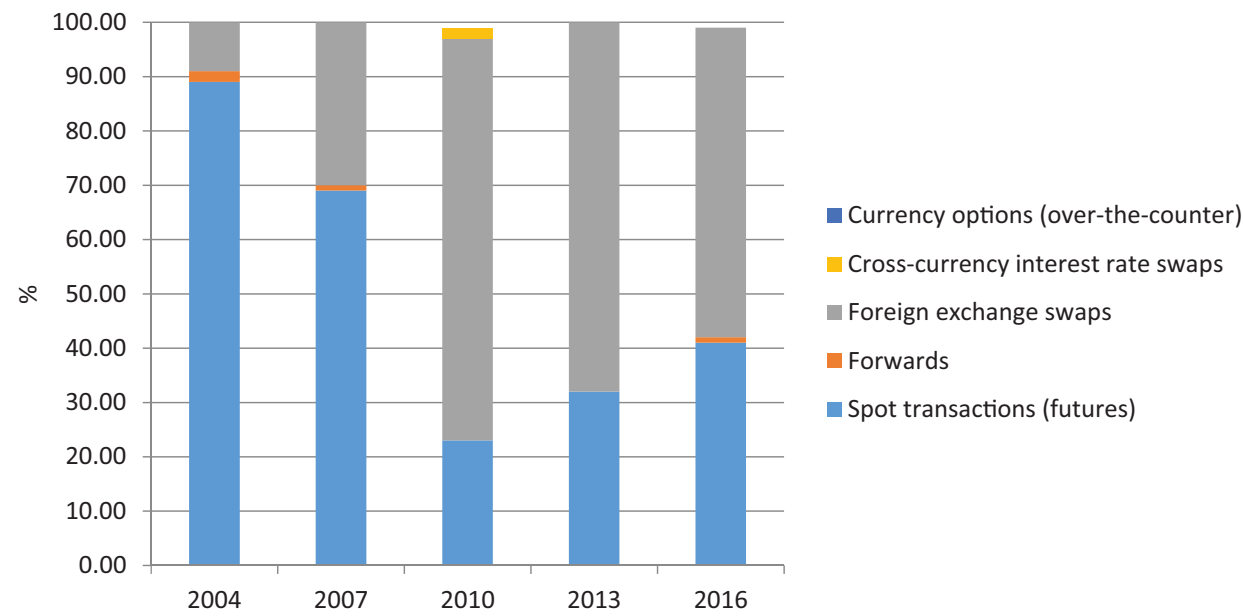

Figure 4. Total turnover by foreign exchange transactions in Lithuania in 2004-2016, in \% (source: developed by the authors based on LB, 2016, 2018; BIS, 2018a, 2018b) 
Data confirm that the Lithuanian derivatives market is becoming increasingly concentrated in the most important Lithuanian banks (LB, 2018). Foreign exchange market participants in Lithuania mostly entered into transactions with other banks participating in the survey (63\%), the majority of which were non-resident banks (67\%). Transactions with other financial institutions accounted for $4 \%$ and non-financial customers - for 33\% (Figure 5) (LB, 2016, 2018, 2019b; BIS, 2018b).

Moreover, Figure 6 summarises the data of Table 1 and identifies the main groups of counterparties (LB, 2016, 2018; BIS, 2018b). It shows that from 2004 until 2016, transactions with cross-border dealers prevailed. In recent years, there has been an upward trend in transactions with local dealers.

Exchange rate risk and the value of both Lithuanian and European enterprises are hedged using derivatives. Most transactions in the Lithuanian foreign exchange market take place in euro and U.S. dollars. An upward trend in the value of the prevailing euro-dollar pair can be observed (Table 2) (LB, 2016, 2018; BIS, 2018a, 2018b). It is likely that having considered the subsequent three-year situation, i.e. after processing data for 2019 , this trend will be preserved.

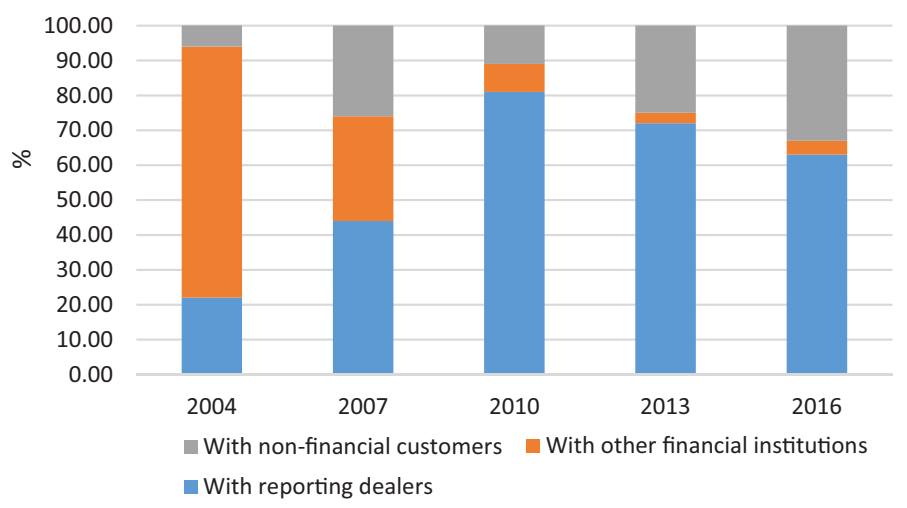

Figure 5. Total turnover by foreign exchange market participants in Lithuania in 2004-2016, in \% (source: developed by the authors based on LB, 2016, 2018, 2019b; BIS, 2018b)

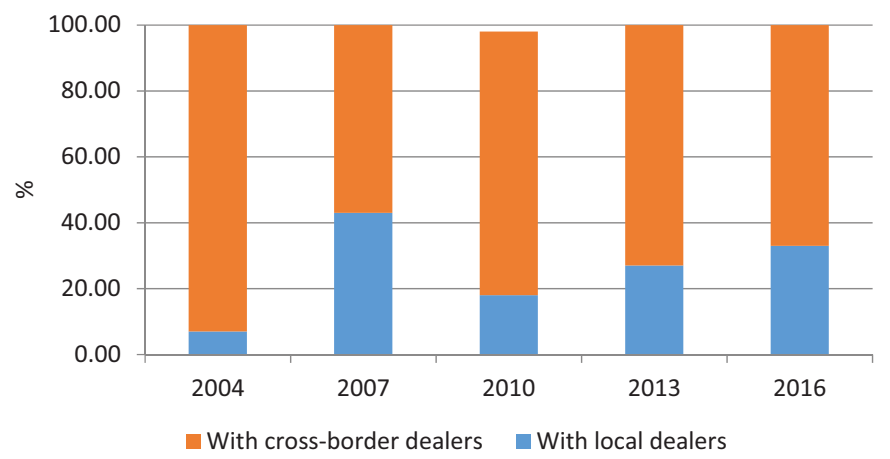

Figure 6. Total turnover by cross-border dealers and local dealers in the Lithuanian foreign exchange market in 2004-2016, in \% (source: developed by the authors based on LB, 2016, 2018, 2019b; BIS, 2018b) 
In summarising the data provided in Table 2, the situation is more vividly shown by Figure 7, which presents the structure of the Lithuanian foreign exchange market (LB, 2016, 2018; BIS 2018a, 2018b). Figure 7 shows that the euro and the U.S. dollar are the main currencies traded on the market, and the euro-dollar pair transactions have prevailed over the past few years (LB, 2016, 2018; BIS, 2018a, 2018b).

Table 2. Turnover in the Lithuanian foreign exchange market by currency pairs (nominal or notional amounts in 2016; millions of U.S. dollars) (source: LB, 2016, 2018; BIS, 2018a)

\begin{tabular}{|l|c|c|c|c|c|c|c|c|c|c|}
\hline \multirow{2}{*}{ Currency pairs } & \multicolumn{2}{|c|}{2004} & \multicolumn{2}{|c|}{2007} & \multicolumn{2}{c|}{2010} & \multicolumn{2}{c|}{2013} & \multicolumn{2}{c|}{2016} \\
\cline { 2 - 13 } & amount & $\begin{array}{c}\text { share, } \\
\%\end{array}$ & amount & $\begin{array}{c}\text { share, } \\
\%\end{array}$ & amount & $\begin{array}{c}\text { share, } \\
\%\end{array}$ & amount & $\begin{array}{c}\text { share, } \\
\%\end{array}$ & amount & $\begin{array}{c}\text { share, } \\
\%\end{array}$ \\
\hline LT / USD & 409.4 & 2 & 628.5 & 4 & 237.6 & 1 & 239.9 & 2 & - & - \\
\hline LT / EUR & 3872.8 & 18 & 9692.0 & 56 & 19669.1 & 81 & 8496.1 & 77 & - & - \\
\hline USD / EUR & 5219.4 & 24 & 4403.6 & 25 & 2049.3 & 8 & 1374.4 & 12 & 3797.4 & 78 \\
\hline USD / GBP & 475.2 & 2 & 39.2 & 0 & 29.1 & 0 & 2.8 & 0 & 74.1 & 2 \\
\hline $\begin{array}{l}\text { USD / other } \\
\text { currencies }\end{array}$ & 11544.4 & 53 & 456.6 & 3 & 594.3 & 2 & 71.4 & 1 & 7.7 & 0 \\
\hline $\begin{array}{l}\text { EUR / other } \\
\text { currencies }\end{array}$ & 411.3 & 2 & 1903.8 & 11 & 771.1 & 3 & 651.7 & 6 & 120.0 & 2 \\
\hline $\begin{array}{l}\text { Other currency } \\
\text { pairs }\end{array}$ & 52.9 & 0 & 215.9 & 1 & 887.4 & 4 & 252.3 & 2 & 898.5 & 18 \\
\hline $\begin{array}{l}\text { All currency } \\
\text { pairs }\end{array}$ & 21985.5 & 100 & 17339.5 & 100 & 24237.8 & 100 & 11088.6 & 100 & 4898.0 & 100 \\
\hline
\end{tabular}

The latest data from 2016 show that the Lithuanian OTC derivatives (interest rate) market was rather modest, just as previously. The turnover of interest rate contracts in the market amounted to 389.5 million U.S. dollars (Table 3) (LB, 2016, 2018; BIS, 2018a, 2018b). It is likely that having considered the subsequent three-year situation, i.e. after processing data for 2019, this situation will look different.

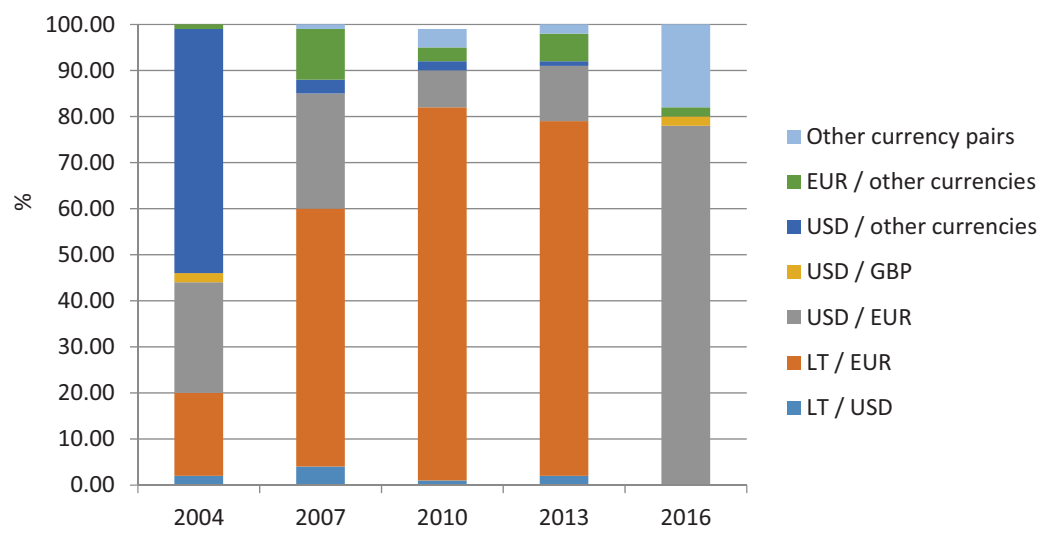

Figure 7. Turnover in the Lithuanian foreign exchange market by currency pairs (source: developed by the authors based on LB, 2016, 2018, 2019a; BIS, 2018a, 2018b) 
Table 3. Turnover in the Lithuanian OTC derivatives market in 2016 by transactions and counterparty (nominal or notional amounts; millions of U.S. dollars) (source: LB, 2016, 2018; BIS, 2018a, 2018b)

\begin{tabular}{|c|c|c|c|c|c|c|c|c|c|c|}
\hline \multirow{2}{*}{$\begin{array}{l}\text { Transactions and } \\
\text { counterparty }\end{array}$} & \multicolumn{2}{|c|}{2004} & \multicolumn{2}{|c|}{2007} & \multicolumn{2}{|c|}{2010} & \multicolumn{2}{|c|}{2013} & \multicolumn{2}{|c|}{2016} \\
\hline & amount & $\begin{array}{c}\text { share, } \\
\%\end{array}$ & amount & $\begin{array}{c}\text { share, } \\
\%\end{array}$ & amount & $\begin{array}{c}\text { share, } \\
\%\end{array}$ & amount & $\begin{array}{c}\text { share, } \\
\%\end{array}$ & amount & $\begin{array}{c}\text { share, } \\
\%\end{array}$ \\
\hline $\begin{array}{l}\text { Forward rate } \\
\text { agreements }\end{array}$ & 125.6 & 100 & - & - & - & - & - & - & - & - \\
\hline $\begin{array}{l}\text { - with reporting } \\
\text { dealers }\end{array}$ & 125.6 & 100 & - & - & - & - & - & - & - & - \\
\hline $\begin{array}{l}\text { - with other financial } \\
\text { institutions }\end{array}$ & - & - & - & - & - & - & - & - & - & - \\
\hline $\begin{array}{l}\text { - with non-financial } \\
\text { customers }\end{array}$ & - & - & - & - & - & - & - & - & - & - \\
\hline Interest rate swaps & - & - & 136.5 & 14 & 420.0 & 98 & - & - & 161.9 & 42 \\
\hline $\begin{array}{l}\text { - with reporting } \\
\text { dealers }\end{array}$ & - & - & 136.5 & 100 & 211.3 & 50 & - & - & 97.1 & 60 \\
\hline $\begin{array}{l}\text { - with other financial } \\
\text { institutions }\end{array}$ & - & - & - & - & - & - & - & - & - & - \\
\hline $\begin{array}{l}\text { - with non-financial } \\
\text { customers }\end{array}$ & & - & - & - & 208.6 & 50 & - & - & 64.9 & 40 \\
\hline Interest rate options & - & - & 807.1 & 85 & 9.4 & 2 & - & - & 227.6 & 58 \\
\hline $\begin{array}{l}\text { - with reporting } \\
\text { dealers }\end{array}$ & - & - & 403.5 & 50 & 8.1 & 86 & - & - & 113.8 & 50 \\
\hline $\begin{array}{l}\text { - with other financial } \\
\text { institutions }\end{array}$ & - & - & - & - & - & - & - & - & - & - \\
\hline $\begin{array}{l}\text { - with non-financial } \\
\text { customers }\end{array}$ & - & - & 403.5 & 50 & 1.3 & 14 & - & - & 113.8 & 50 \\
\hline $\begin{array}{l}\text { Total OTC derivatives } \\
\text { market }\end{array}$ & 125.6 & 100 & 943.5 & 100 & 429.4 & 100 & - & - & 389.5 & 100 \\
\hline $\begin{array}{l}\text { - with reporting } \\
\text { dealers }\end{array}$ & 125.6 & 100 & 540.0 & 57 & 219.4 & 51 & - & - & 210.8 & 54 \\
\hline $\begin{array}{l}\text { - with other financial } \\
\text { institutions }\end{array}$ & - & - & - & - & - & - & - & - & - & - \\
\hline $\begin{array}{l}\text { - with non-financial } \\
\text { customers }\end{array}$ & - & - & 403.5 & 43 & 210.0 & 49 & - & - & 178.6 & 46 \\
\hline - local & - & - & 403.5 & 43 & 210.0 & 49 & - & - & 62.0 & 16 \\
\hline - cross-border & 125.6 & 99 & 540 & 57 & 219.4 & 51 & - & - & 328.0 & 84 \\
\hline
\end{tabular}

The Bank for International Settlements publishes on its website (LB, 2018; BIS, 2018a, 2018 b) preliminary data of triennial surveys of global foreign exchange and derivatives markets. The purpose of the BIS surveys is to obtain comprehensive and internationally comparable statistical information on the size and structure of the foreign exchange and OTC derivatives markets (LRS, 2007; BIS, 2018a, 2018b). It can be claimed that this is an exclusive and unique, all-inclusive and reliable survey which since 1996 has provided financial markets with key guidance on the derivatives market (BIS, 2018a). 


\section{Forecasting of derivatives transactions and currency pairs}

An analysis and assessment of the situation in derivatives markets reveals that the focus is on foreign exchange transactions as well as currency pairs. According to data of Table 1 and Figure 1, spot transactions (futures) were steadily decreasing from 2004 until 2016 in value terms, however as of 2013 a rise in the foreign exchange market as a whole in terms of percentage was observed. There was a sharp drop in forwards during the period from 2004 to 2016, although modest growth was observed in 2016. Foreign exchange swaps fluctuated sharply during 2004-2016, with their value and percentage in the foreign exchange market as a whole surging in 2010. However, a downward trend in both value and percentage terms was seen subsequently.

In order to examine in more detail the dynamics, over recent decades, and expected trends of derivative financial instruments, a forecast of foreign exchange transactions was carried out using the weighted moving average method and various functions (exponential, linear, logarithmic, polynomial, power, etc.). The forecasts of foreign exchange transactions using the weighted moving average method (Figure 8) reveal that spot transactions (futures) and FX swaps account for the major part of the foreign exchange market. The forecasts of these transactions over a few more fixed-duration (three-year) periods ahead show that FX swaps prevail, though there is also a substantial volume of spot transactions (futures). Trends in these transactions do not project any major changes when forecasted using the weighted moving average method. Slight fluctuations are to be noted.

As spot transactions (futures) stand out in terms of their value and percentage, their forecasting was carried out by applying various functions, such as exponential, linear, logarithmic, polynomial, power, etc. Upon analysing the obtained results and graphs according to various functions, the function with the highest coefficient of determination, and thus the correlation coefficient, i.e., $R^{2}=0.8899$ (Figure 9), was selected for forecasting purposes. An analysis of the trends in spot transactions forecasted by applying a polynomial function

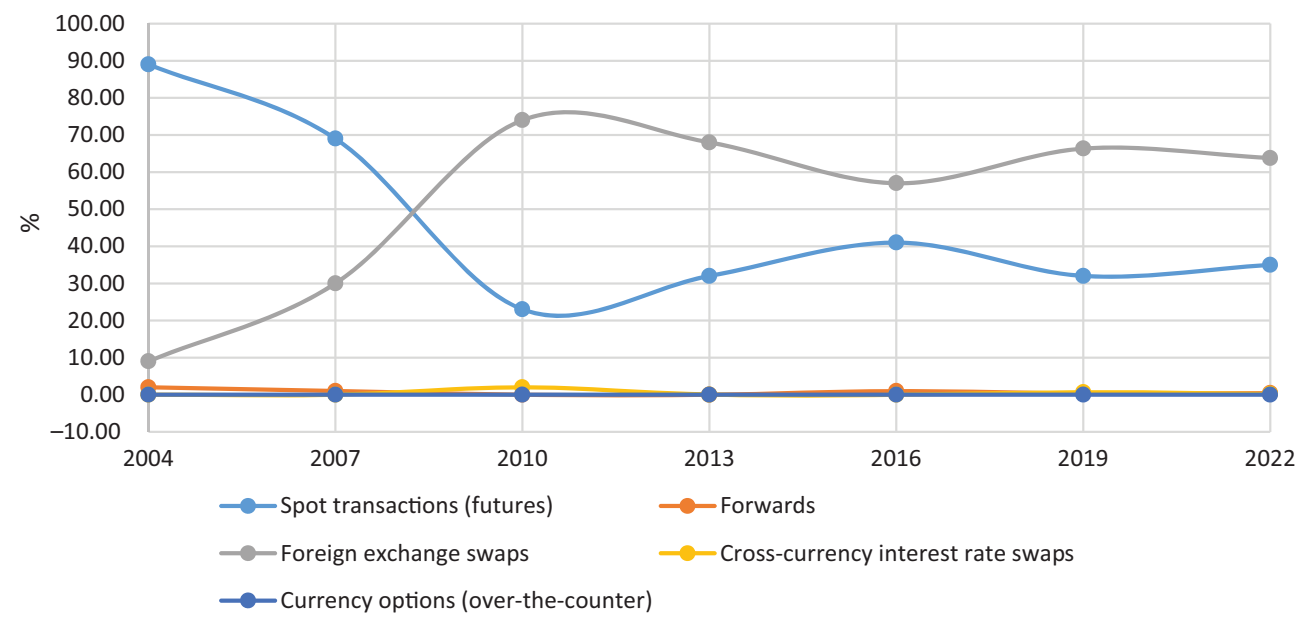

Figure 8. Forecast of the Lithuanian foreign exchange market according to the weighted moving average method

(source: developed by the authors based on LB, 2016, 2018, 2019b; BIS, 2018a, 2018b) 


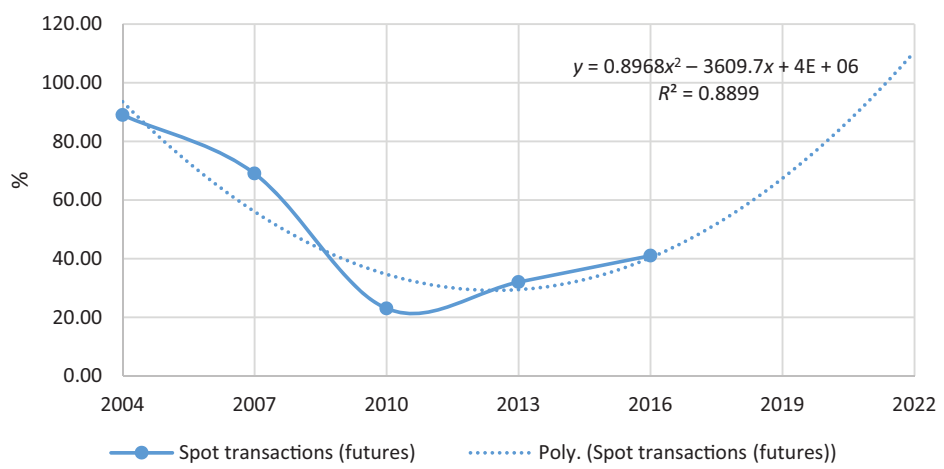

Figure 9. Forecast of spot transactions (futures) based on factual data and applying a polynomial function

(source: developed by the authors based on LB, 2016, 2018, 2019b; BIS, 2018a, 2018b)

predicts a sharp increase in the percentage of these transactions in the future. The forecasts using the weighted moving average method also project an upward trend in the future, though less marked.

FX swaps also stand out in terms of their value and percentage among all transactions under study (Table 1, Figure 1), therefore their forecasting was carried out using various functions, such as exponential, linear, logarithmic, polynomial, power, etc. Upon analysing the obtained results and graphs according to various functions, the function with the highest coefficient of determination, and thus the correlation coefficient, i.e., $R^{2}=0.9076$ (Figure 10), was selected for forecasting purposes. An analysis of trends in FX swaps forecasted by applying a polynomial function foresees a sharp drop in the percentage of these transactions in the future. The forecasts using the weighted moving average method also project a downward trend in the future, though less marked.

In order to examine in more detail the dynamics, over recent decades, and expected trends of currency pairs (Table 2, Figure 7), currency pair forecasting was carried out using the weighted moving average method and various functions (exponential, linear, logarithmic, polynomial,

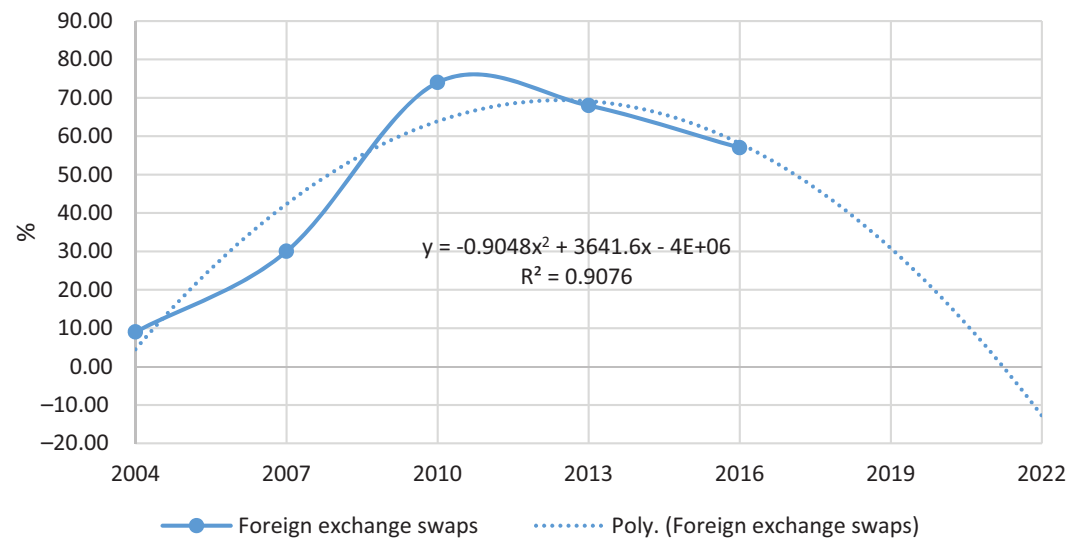

Figure 10. Forecast of FX swaps based on factual data and applying a polynomial function (source: developed by the authors based on LB, 2016, 2018, 2019b; BIS, 2018a, 2018b) 
power, etc.). The forecast of currency pairs using the weighted moving average method (Figure 11) shows that the LT/EUR and USD/EUR pairs account for the largest share of the currency pair market as a whole. The forecast of these pairs over a few fixed-duration (three-year) periods ahead reveals that the USD/EUR pair prevails, however other currency pairs also have substantial volumes. Trends in respect of these pairs, forecasted using the weighted moving average method, do not project significant changes in the future. Slight fluctuations are to be noted. The LT/EUR pair was no longer in use as of 2015, hence a sharp rise of the USD/EUR pair could be observed during 2015-2016, with these trends expected to stabilise later.

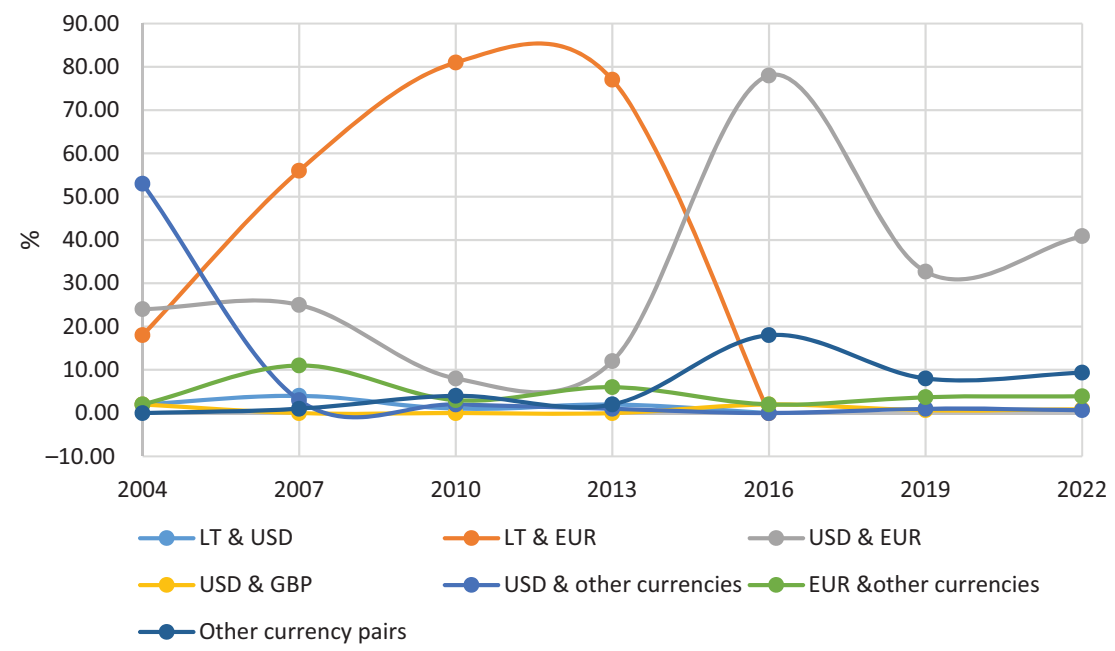

Figure 11. Forecast of currency pairs according to the weighted moving average method (source: developed by the authors based on LB, 2016, 2018, 2019b; BIS, 2018a, 2018b)

As the USD/EUR pair stands out in terms of value and percentage, its forecasting using various functions, such as exponential, linear, logarithmic, polynomial, power, etc., was carried out. Upon analysing the obtained results and graphs according to various functions, the function with the highest coefficient of determination, and thus the correlation coefficient, i.e., $R^{2}=0.7982$ (Figure 12), was selected for forecasting purposes. The trends in the USD/ EUR pair forecasted by applying a polynomial function show a significant increase in the percentage of this pair in the future. The forecast carried out according to the weighted moving average method also projects a future upward trend, though less marked.

Among all currency pairs, the pair EUR/other currencies could be distinguished due to its value and percentage (Table 2, Figure 4), therefore it was forecasted using various functions, such as exponential, linear, logarithmic, polynomial, power, etc. Upon analysing the obtained results and graphs according to various functions, the function with the highest coefficient of determination, and thus the correlation coefficient, i.e., $R^{2}=0.3158$ (Figure 13), was selected for forecasting purposes. An analysis of trends in respect of this currency pair forecasted with a polynomial function projects a substantial decline in the percentage of these transactions in the future. The forecast using the weighted moving average method also projects a downward trend in the future, though less marked. 


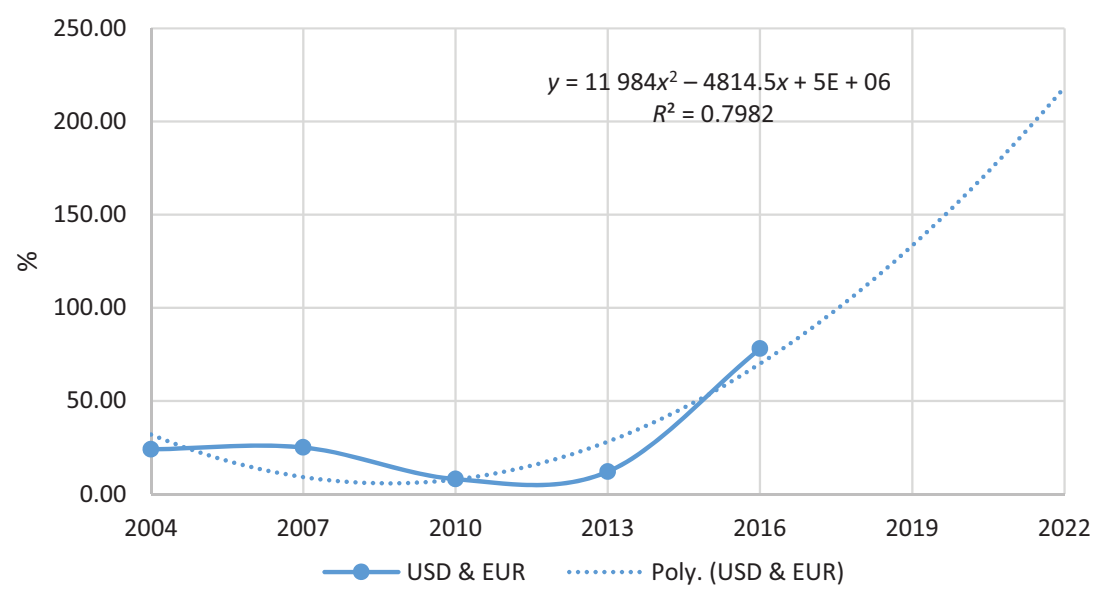

Figure 12. Forecast of the USD/EUR currency pair based on factual data and applying a polynomial function

(source: developed by the authors based on LB, 2016, 2018, 2019b; BIS, 2018a, 2018b)

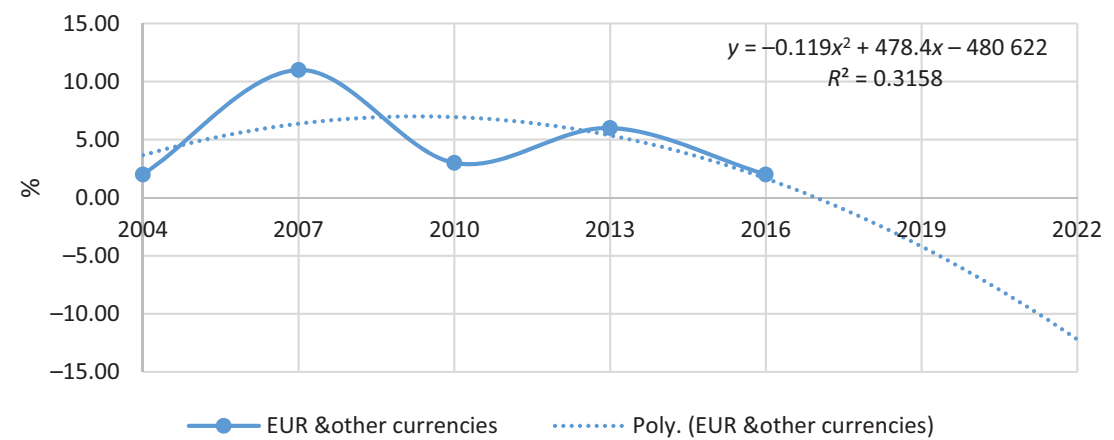

Figure 13. Forecast of the pair EUR/other currencies based on factual data and applying a polynomial function

(source: developed by the authors based on LB, 2016, 2018, 2019b; BIS, 2018a, 2018b)

In order to examine in more detail the dynamics, over recent decades, and expected trends of derivatives and currency pairs, foreign exchange transactions and currency pairs were forecasted using the weighted moving average method and various functions (exponential, linear, logarithmic, polynomial, power, etc.). Foreign exchange transaction forecasting using the weighted moving average method and according to various functions shows that in the foreseen period, currency swaps will prevail, though there is also a significant volume of spot transactions (futures). Trends in these transactions do not project major changes.

The forecasting of currency pairs using the weighted moving average method and various functions allows to predict that in the foreseen period, the USD/EUR pair will prevail, while other currency pairs also demonstrate substantial volumes. The trends observed in respect of these pairs do not project any major changes in the future. 


\section{Conclusions}

It can be claimed that derivatives, if used properly, allow for effective management of various risks faced by business entities. Hedging through the use of derivatives enables businesses to reduce risk and distribute risk among individual market participants. The derivatives can be used to manage not only currency, interest rate, commodity, and credit risks, but also the overall risk of emergence of any adverse effects.

The recent situation, viewed from the perspective of growing international tension, makes it necessary to re-examine the past crisis, its causes and consequences. It is recalled that the 2007-2008 global financial crisis revealed the challenges and risks of derivative financial instruments and demonstrated the tremendous impact that their imprudent use can have on the stability of a financial system. Derivatives, which were supposed to assist financial institutions as regards hedging and diversification of risk, became one of the causes of the crisis, and as a result of the globalisation and integration of the financial market the crisis that had begun in the USA grew into a global financial crisis.

As an implication for the present, the past financial crisis showed the need to implement a certain package of measures to address the issues emerging in this market. These measures include regulation of the derivatives market and standardisation of the instruments themselves and credit rating activities, as well as improvement of the market infrastructure itself. Moreover, the crisis also revealed the shortcomings of derivatives in terms of insufficient risk monitoring, absence of market regulation, lack of standardisation, systemic market risk, high market concentration, price distortions and emergence of inadequate credit ratings. The global financial crisis highlighted these issues in the derivatives market and the riskiness of the market in these instruments as well as their dangerous impact on the overall stability of a financial system. However, it would be unreasonable to abandon the instruments that filled the niche emerging in present-day markets, and use should be made of the specific features of these instruments in the context of the development of financial markets.

The forecasting of derivative financial instruments and currency pairs using the weighted moving average method and various functions (exponential, linear, logarithmic, polynomial, power, etc.) has yielded certain results concerning a foreseen future period. Foreign exchange transaction forecasting shows that currency swaps will prevail in the future, but there is also a significant volume of spot transactions (futures). Currency pair forecasting reveals that the USD/EUR pair will prevail in the future, however other currency pairs also demonstrate substantial volumes.

In the derivatives market, it is necessary to implement certain measures to improve the infrastructure of the derivatives market, improve liquidity assistance in financial markets, review credit rating mechanisms and methodologies, and create an adequate supervisory framework.

A rapidly developing derivatives market creates prerequisites for a better distribution of risk within a financial system by enhancing the stability of the financial system. Derivatives can make risk management more efficient and flexible, especially in banks, and can also result in a more effective distribution of individual risks and reduction of the overall economic risk associated with them. 
In the absence of an adequate supervisory framework, it is important to ensure the means of prudential treatment of derivatives: stricter regulation of investment banking activities; establishment of a regulatory and supervisory mechanism for the financial institutions using financial instruments; disclosure of information on supervision in different financial markets; assessment of the impact of new financial instruments on a financial system; ensuring of the transparency of methodologies and independence of assessment.

The paper includes analysis of the risks for the underlying risks stemming from the derivatives market. Limitations and difficulties were encountered in the research. It has been difficult to find the necessary data related to new financial instruments and their impact on the financial system. Information on derivatives is provided every three years (the last will be provided in 2021). The possibilities for future research should be greater and wider. Future research is expected to include analysis about derivative pricing, their growth rates compared to the real economy, or the derivatives risks on the financial and the banking system.

\section{References}

Akbar, S., Rehman, S., \& Ormrod, P. (2013). The impact of recent financial shocks on the financing and investment policies of UK private firms. International Review of Financial Analysis, 26, 59-72. https://doi.org/10.1016/j.irfa.2012.05.004

Aysun, U., \& Guldi, M. (2011). Derivatives market activity in emerging markets and exchange rate exposure. Emerging Markets Finance and Trade, 47(6), 46-58. https://doi.org/10.2753/REE1540-496X470603

Bae, S. C., Kim H., S. K., \& Kwon, T. H. (2017). Currency derivatives for hedging: New evidence on determinants, firm risk, and performance. Journal of Futures Markets, 38(4), 446-467. https://doi.org/10.1002/fut.21894

Bank for International Settlements. (2014). Impact assessment of OTC derivatives regulatory reforms. Basle.

Bank for International Settlements. (2018a). Exchange-traded derivatives statistics. https://www.bis.org/ statistics/extderiv.htm? $\mathrm{m}=6 \% 7 \mathrm{C} 32 \% 7 \mathrm{C} 616$

Bank for International Settlements. (2018b). Triennial Central Bank Survey of foreign exchange and OTC derivatives markets in 2004-2016. https://www.bis.org/publ/rpfx16.htm

Bardoscia, M., Bianconi, G., \& Ferrara, G. (2019). Multiplex network analysis of the UK OTC derivatives market (Working Paper No. 726). Bank of England. https://doi.org/10.2139/ssrn.3180709

Barron, A., \& Hultén, P. (2011). Corporate political strategizing in the European Union during the 2007-2013 Recession: An Exploratory Study. Environment and Planning C: Government and Policy, 29(5), 783-796. https://doi.org/10.1068/c10165b

Bartram, S. M., Brown, G. B., \& Fehle, F. (2009). International evidence on financial derivatives usage. Financial Management, 38(1), 185-206. https://doi.org/10.1111/j.1755-053X.2009.01033.x

Begg, I. (2009). Regulation and supervision of financial intermediaries in the EU: The Aftermath of the Financial Crisis. JCMS: Journal of Common Market Studies, 47(5), 1107-1128. https://doi.org/10.1111/j.1468-5965.2009.02037.x

Bezzina, F. H., \& Grima, S. (2012). Exploring factors affecting the proper use of derivatives. Managerial Finance, 38(4), 414-417. https://doi.org/10.1108/03074351211207554

Bingham, N. H., \& Rüdiger, K. (2013). Risk-neutral valuation - pricing and hedging of financial derivatives $\left(5^{\text {th }}\right.$ ed.). Springer Verlag. 
Blanco, I., \& Wehrheim, D. (2017). The bright side of financial derivatives: Options trading and firm innovation. Journal of Financial Economics, 125(1), 99-119.

https://doi.org/10.1016/j.jfineco.2017.04.004

Borger, V. (2020). The currency of solidarity. Constitutional transformation during the Euro Crisis. Cambridge University Press. https://doi.org/10.1017/9781108864633

Braendle, U. (2018). The impact of the European Banking Union's Single Supervisory Mechanism on corporate governance practices in European banks. Banks and Bank Systems, 13(2), 164-177. https://doi.org/10.21511/bbs.13(2).2018.14

Brigham, E. F., \& Davies, P. R. (2016). Intermediate financial management $\left(12^{\text {th }}\right.$ ed.). South-Western College Pub.

Burns, C., Tobin, P., \& Sewerin, S. (2019). The impact of the economic crisis on European environmental policy. Oxford University Press. https://doi.org/10.1093/oso/9780198826958.001.0001

Burns, C., \& Tobin, P. (2016). The impact of the economic crisis on European Union environmental policy. JCMS: Journal of Common Market Studies, 54(6), 1485-1494. https://doi.org/10.1111/jcms.12396

Carroll, A., O’Brien, F., \& Ryan, J. (2017). An examination of European firms' derivatives usage: The importance of model selection. European Financial Management, 23(4), 648-690. https://doi.org/10.1111/eufm.12115

Carruthers, B. G. (2013). Diverging derivatives: Law, governance and modern financial markets. Journal of Comparative Economics, 41(2), 386-400. https://doi.org/10.1016/j.jce.2013.03.010

Chang, C. C., Ho, K. H., \& Hsiao, I. J. (2018). Derivatives usage for banking industry: evidence from the European markets. Review of Quantitative Finance and Accounting, 51(4), 921-941. https://doi.org/10.1007/s11156-017-0692-3

Crotty, J. (2009). Structural causes of the global financial crisis: A critical assessment of the "new financial architecture". Cambridge Journal of Economics, 33(4), 563-580. https://doi.org/10.1093/cje/bep023

David, G. (2009). Did recent experience of a financial crisis help in coping with the current financial turmoil? The case of the Nordic Countries. JCMS: Journal of Common Market Studies, 47(5), 997-1015. https://doi.org/10.1111/j.1468-5965.2009.02032.x

Donohoe, M. P. (2015). Financial derivatives in corporate tax avoidance: A conceptual perspective. The Journal of the American Taxation Association, 37(1), 37-68. https://doi.org/10.2308/atax-50907

Eilifsen, A., \& Quick, R. (2018). Florian Schmidt and Steffen Umlauf, Investors' perceptions of nonaudit services and their type in Germany: The financial crisis as a turning point. International Journal of Auditing, 22(2), 298-316. https://doi.org/10.1111/ijau.12121

Foster, J. B., \& Magdoff, F. (2009). The great financial crisis - causes and consequences. NYU Press.

Garskaite-Milvydiene, K., \& Burksaitiene, D. (2016). Peculiarities of bankruptcies, restructuring, mergers and acquisitions in Lithuania in the post-crisis period. Inzinerine Ekonomika-Engineering Economics, 27(5), 546-556. https://doi.org/10.5755/j01.ee.27.5.16241

Gay, G. D., Lin, C. M., \& Smith, S. D. (2011). Corporate derivatives use and the cost of equity. Journal of Banking \& Finance, 35(6), 1491-1503. https://doi.org/10.1016/j.jbankfin.2010.10.033

Geyer-Klingeberg, J. G., Hang, M., \& Rathgeber, A. W. (2018). What drives financial hedging? A metaregression analysis of corporate hedging determinants. International Review of Financial Analysis, 2019, 61, 203-221. https://doi.org/10.2139/ssrn.3164869

Gródek-Szostak, Z., Malik, G., Kajrunajtys, D., Szeląg-Sikora, A., Sikora, J., Kuboń, M., Niemiec, M., \& Kapusta-Duch, J. (2019). Modeling the dependency between extreme prices of selected agricultural products on the derivatives market using the linkage function. Sustainability, 11(15), 4144.

https://doi.org/10.3390/su11154144 
Hentschel, L., \& Smith, C. (2020). Risk and regulation in derivatives (or why derivatives are a blessing, not a curse). Journal of Applied Corporate Finance, 32(1), 36-37. https://doi.org/10.1111/jacf.12387

Hoa, N., Liu, M. H., \& Gallagher, D. (2013). Effective derivative hedging and initial public offering long-run performance. Accounting \& Finance, 54(4), 1263-1294. https://doi.org/10.1111/acfi.12036

Höing, O., \& Kunstein, T. (2018). Political science and the eurozone crisis. A review of scientific journal articles 2004-15. JCMS: Journal of Common Market Studies, 57(2), 298-316.

https://doi.org/10.1111/jcms.12788

Hull, J. (2012). Options, futures, and other derivatives. Pearson.

Iba, H., \& Aranha, C. C. (2012). Practical applications of evolutionary computation to financial engineering: Robust techniques for forecasting, trading and hedging. Springer.

Inekwe, J. (2018). Financial crises and the extreme bounds of predictors. Empirical Economics, 55(4), 2047-2067. https://doi.org/10.1007/s00181-017-1352-0

Jacopo, C., Gros, D., \& Micossi, S. (2009). The global financial crisis: Causes and cures. Journal of Common Market Studies, 47(5), 977-996. https://doi.org/10.1111/j.1468-5965.2009.02031.x

Jankensgard, H. (2013). Does centralisation of FX derivative usage impact firm value? European Financial Management, 21(2), 309-332. https://doi.org/10.1111/j.1468-036X.2013.12014.x

Kazi, I. A., Wagan, H., \& Akbar, F. (2013). The changing international transmission of U.S. monetary policy shocks: Is there evidence of contagion effect on OECD countries. Economic Modelling, 30, 90-116. https://doi.org/10.1016/j.econmod.2012.07.020

Kosowski, R. L., \& Neftci, S. N. (2015). Principles of financial engineering. Academic Press Advanced Finance. https://doi.org/10.1016/B978-0-12-386968-5.00012-1

Lel, U. (2014). Currency hedging and corporate governance: A cross-country analysis. Journal of Corporate Finance, 18(2), 221-225. https://doi.org/10.1016/j.jcorpfin.2011.12.002

Li, Sh., \& Marinc, M. (2014). The use of financial derivatives and risks of U.S. bank holding companies. International Review of Financial Analysis, 35, 46-71. https://doi.org/10.1016/j.irfa.2014.07.007

Lietuvos bankas. (2016). Užsienio valiutos pirkimas ir pardavimas [Purchase and sale of foreign currency]. http://www.lb.lt/int/htm.aspx

Lietuvos bankas. (2018). Lietuvos valiutų ir išvestiniu finansinių priemoniu rinkų apžvalga [Review of Lithuanian foreign exchange and derivatives markets]. http://www.lb.lt/2016_m_lietuvos_valiutu_ ir_isvestiniu_finansiniu_priemoniu_rinku_apzvalga

Lietuvos bankas. (2019a). Lietuvos valiutų ir išvestiniu finansiniu priemoniu rinkų apžvalga [Review of Lithuanian foreign exchange and derivatives markets]. http://www.lb.lt/2019_m_lietuvos_valiutu_ ir_isvestiniu_finansiniu_priemoniu_rinku_apzvalga

Lietuvos bankas. (2019b). Užsienio valiutos pirkimas ir pardavimas [Purchase and sale of foreign currency]. http://www.lb.lt/int/htm.aspx

Lietuvos Respublikos Seimas. (2007). Finansiniu priemoniu rinkos įstatymas [Law on Markets in Financial Instruments]. http://www3.lrs.lt/pls/inter2/dokpaieska.showdoc_l?p_id=291835\&p_ query $=\& p \_t r 2=$

Marshall, A., Kemmitt, M., \& Pinto, H. (2013). The determinants of foreign exchange hedging in Alternative Investment Market firms. The European Journal of Finance, 19(2), 89-100. https://doi.org/10.1080/1351847X.2012.659267

Mayordomo, S., Rodriguez-Moreno, M., \& Pena, J. I. (2014). Derivatives holdings and systemic risk in the U.S. banking sector. Journal of Banking and Finance, 45, 84-104. https://doi.org/10.1016/j.jbankfin.2014.03.037

McKibbin, W. J., \& Stoeckel, A. (2010). The global financial crisis: Causes and consequences. Asian Economic Papers, The MIT Press, 9(1), 54-86. https://doi.org/10.1162/asep.2010.9.1.54 
Melvin, M., \& Taylor, M. P. (2009). The global financial crisis: Causes, threats and opportunities. Introduction and overview. Journal of International Money and Finance, 28(8), 1243-1245. https://doi.org/10.1016/j.jimonfin.2009.08.002

Müller, M. A., Riedl, E., \& Sellhorn, T. (2015). Recognition versus disclosure of fair values. The Accounting Review, 90(6), 2411-2447. https://doi.org/10.2308/accr-51044

Murphy, D. (2013). OTC derivatives: Bilateral trading \& central clearing: An introduction to regulatory policy, market impact and systemic risk. Palgrave Macmillan. https://doi.org/10.1057/9781137293862_7

Naiker, V., Navissi, F., \& Truong, C. (2013). Options trading and the cost of equity capital. The Accounting Review, 88(1), 261-295. https://doi.org/10.2308/accr-50275

Nedelchev, M. (2018). Coordination of banking supervision in the European Union. Economy of Industry, 83(3), 43-56. https://doi.org/10.15407/econindustry2018.03.043

Obstfeld, M., \& Rogoff, K. S. (2009). Global imbalances and the financial crisis: Products of common causes (CEPR Discussion Paper No. DP7606). https://ssrn.com/abstract=1533211

Oldani, C. (2018). Global financial regulatory reforms and sovereign's exemption. Journal of Financial Regulation and Compliance, 26(2), 190-202. https://doi.org/10.1108/JFRC-11-2016-0105

Oldani, C. (2008). Governing global derivatives: Challenges and risks. Taylor and Francis.

Parlapiano, F., Alexeev, V., \& Dungey, M. (2017). Exchange rate risk exposure and the value of European firms. The European Journal of Finance, 23(2), 111-129. https://doi.org/10.1080/1351847X.2015.1072570

Quaglia, L. (2013). Financial regulation and supervision in the European Union after the crisis. Journal of Economic Policy Reform, 16(1), 17-30. https://doi.org/10.1080/17487870.2012.755790

Reddy, K. S., Nangia, V. K., \& Agrawal, R. (2014). The 2007-2008 global financial crisis, and crossborder mergers and acquisitions. Global Journal of Emerging Market Economies, 6(3), 257-281. https://doi.org/10.1177/0974910114540720

Rutkauskas, A. V., Miecinskiene, A., \& Stasytyte, V. (2008). Investment decisions modelling along sustainable development concept on financial markets. Technological and Economic Development of Economy, 14(3), 417-427. https://doi.org/10.3846/1392-8619.2008.14.417-427

Sakurai, Y., \& Kurosaki, T. (2020). A simulation analysis of systemic counterparty risk in over-thecounter derivatives markets. Journal of Economic Interaction and Coordination, 15, 243-281. https://doi.org/10.1007/s11403-019-00260-7

Sarveswara Reddy, A., \& Sathish, K. (2020). The importance of the financial derivatives markets to economic development in the world's four major economies. International Journal for Research in Engineering Application \& Management (IJREAM), 6(1), 508-519.

https://doi.org/10.35291/2454-9150.2020.0341

SEB bankas. (2018). Išvestiniu finansiniu priemoniu aprašas [Description of derivatives]. https://www.seb.lt/sites/default/files/PDF/IFP-sandoriu-aprasas.pdf

Shil, N. C., \& Das, B. (2017). Financial management: A strategic perspective. SAGE Publications.

Silvo, D., Festic, M., \& Kavkler, A. (2012). Comovement dynamics between Central and Eastern European and Developed European Stock Markets during European Integration and Amid Financial Crises - A wavelet analysis. Inzinerine Ekonomika-Engineering Economics, 23(1), 22-32. https://doi.org/10.5755/j01.ee.23.1.1221

Su, H. J. C., Joseph, N. L., \& Gilder, D. (2018). Monitoring mechanisms, managerial incentives, investment distortion costs, and derivatives usage. The British Accounting Review, 50(1), 93-115. https://doi.org/10.1016/j.bar.2017.11.004

Swedbank. (2017). Išvestinès finansinès priemonès [Derivatives]. https://www.swedbank.lt/lt/pages/ privatiems/isvestines_finansines_priemones 
Thapa, C., Neupane, S., \& Marshall, M. (2016). Market liquidity risks of foreign exchange derivatives and cross-country equity portfolio allocations. Journal of Multinational Financial Management, 34, 46-64. https://doi.org/10.1016/j.mulfin.2016.01.001

Vo, D. H., Huynh, S. V., Vo, A., \& Nguyen, M. H. (2019a). The importance of the financial derivatives markets to economic development in the World's Four Major Economies. Journal of Risk Financial Management, 12(1), 35. https://doi.org/10.3390/jrfm12010035

Vo, D. H., Nguyen, P. V., Nguyen, M. H., Vo, A. T., \& Nguyen, T. C. (2019b). Derivatives market and economic growth nexus: Policy implications for emerging markets. The North American Journal of Economics and Finance, 48. https://doi.org/10.1016/j.najef.2018.10.014

Wang, C. C. Y. (2017). Commentary on: Implied cost of equity capital estimates as predictors of accounting returns and stock returns. Journal of Financial Reporting, 2(1), 95-106.

https://doi.org/10.2308/jfir-51873 